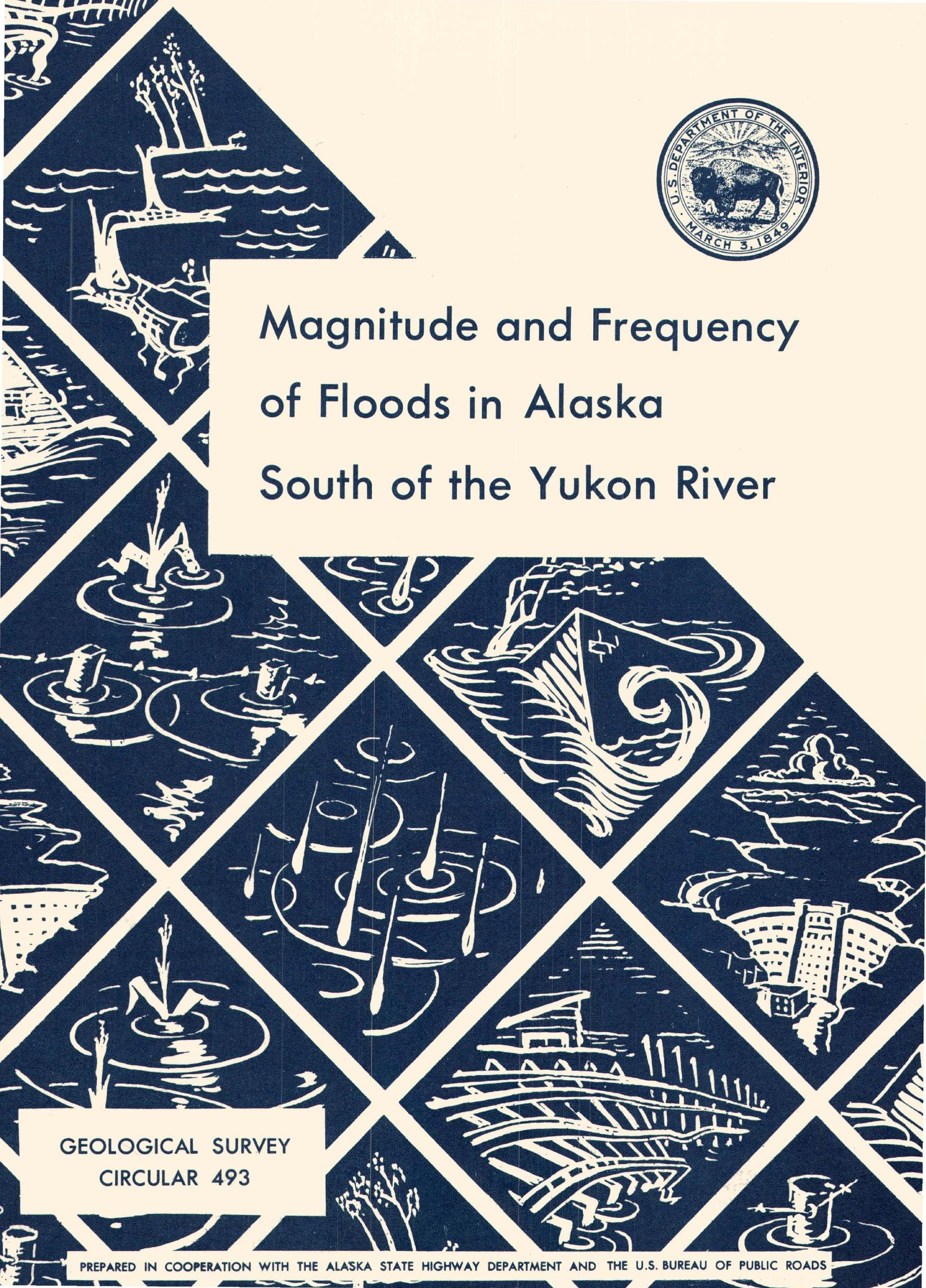




\section{Magnitude and Frequency of Floods in Alaska, South of the Yukon River}

By V. K. Berwick, J. M. Childers, and M. A. Kuentzel

$$
\lambda
$$

Prepared in cooperation with the Alaska State Highway Department and the U.S. Bureau of Public Roads

Geological Survey Circular 493 
United States Department of the Interior STEWART L. UDALL, SECRETARY

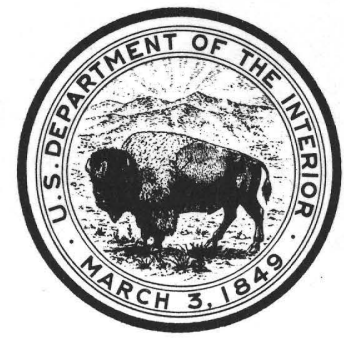

Geological Survey

THOMAS B. NOLAN, Director

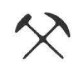

Free on application to the U.S. Geological Survey, Washington, D. C. 20242 


\section{CONTENTS}

\begin{tabular}{|c|c|c|}
\hline \multicolumn{3}{|c|}{ Page } \\
\hline Abstract & 1 & Flood-frequency analysis-Continued \\
\hline Introduction & 1 & Flood-frequency at a gaging \\
\hline Method $\ldots \ldots$ & 1 & station-Continued \\
\hline Physical description of the region & 2 & Plotting positions \\
\hline Area A & 2 & Fitting frequency curves $\ldots \ldots \ldots$ \\
\hline Area B & 2 & Regional flood frequency \\
\hline Area C & 3 & Regional homgeneity of records \\
\hline Climate of the region & 3 & Composite frequency curve \\
\hline Area A & 3 & Mean annual flood \\
\hline Area B & 3 & Hydrologic areas \\
\hline Area C & 3 & Maximum known floods \\
\hline Flood-frequency analysis & 3 & Unusual floods at short-term gaging \\
\hline Records available & 3 & stations \\
\hline Flood-frequency at a gaging station.- & 4 & Summary and conclusions \\
\hline Significance and utilization & 4 & Selected references \\
\hline Types of flood series & 4 & \\
\hline
\end{tabular}

\section{ILLUSTRATIONS}

Plate 1. Map of Alaska showing region covered by flood-frequency study_._........ In pocket Figure 1. Composite flood-frequency curve

$2-4$. Variation of mean annual flood with drainage area:

2. Area A .

3. Area B $\mathrm{B}$

4. Area C

5-7. Relation of maximum to 10 - and 50-year floods:

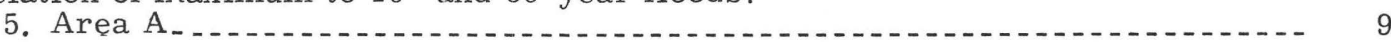

6. Area B

7. Area C

\section{TABLES}

Table. 1. Maximum stages and discharges at gaging stations

2. Unusual floods at short-term gaging stations 


\title{
Magnitude and Frequency of Floods in Alaska, South of the Yukon River
}

\author{
By V. K. Berwick, J. M. Childers, and M. A. Kuentzel ${ }^{1}$
}

\begin{abstract}
This report presents a method for evaluating the magnitude and frequency of floods on the basis of the analysis of flood records. One composite frequency curve is applied to the entire study region. This curve relates floods of various magnitudes at any site within the region to probable recurrence intervals (from 1.1 to 50 years) for those floods. Flood magnitudes are reduced to dimensionless form by expressing them as a ratio to mean annual flood. Magnitudes of mean annual floods vary with the flood-producing characteristics of stream basins. On the basis of the limited data available, drainage-area size is found to be the only significant factor affecting the magnitude of the mean annual flood. Trial and error groupings of gaging-station records show that the region can be split into three hydrologic areas; one curve defines the relation within each area between mean annual flood and drainage area. These three curves in combination with the composite flood-frequency curve permit, for natural-flow conditions at any site, the determination of flood magnitude for a given recurrence interval, or the determination of recurrence interval for a flood of known magnitude.
\end{abstract}

\section{INTRODUCTION}

Knowledge of the magnitude and frequency of recurrence of floods provides a basis for economical design of structures to be located in the flood plains of streams. Such structures are usually designed to accommodate a flood whose average frequency of occurrence is about equal to the expected useful life of the structure. If structural failure will likely cause loss of life, design is usually based on the maximum probable flood.

This report describes a method of determining the magnitude and frequency of floods for most sites in Alaska south of the Yukon River. The methods described can be used generally within the specified limits except for unusual flood conditions. Some noteworthy unusual flood conditions that are not analyzed in this study are associated with the occurrence of natural storage releases from glacier-dammed lakes. Evaluation of the effect that man's activities within the basins has on floods is also beyond the scope of this study.
The report was prepared in the Juneau office of the U.S. Geological Survey under the direction of Ralph E. Marsh, district engineer, Surface Water Branch, in cooperation with the State of Alaska, Department of Highways, and the U.S. Bureau of Public Roads.

\section{METHOD}

The U.S. Geological Survey method of floodfrequency analysis is as follows:

1. A flood-frequency curve for each individual gaging site is defined by using the streamflow records for that site to relate annual peak flows, expressed in cubic feet per second (cfs), to recurrence interval.

2. Regions are defined within which floodfrequency characteristics are similar. Floodfrequency curves for individual stations within a region are combined to form a regional or composite flood-frequency curve in which discharge magnitude is expressed as a dimensionless ratio to mean annual flood.

3. For each region, areas are defined within which flood-producing characteristics are similar. For all gaging stations within an area, the mean annual flood, as determined from individual station records in step 1 above, is related graphically to one or more basin characteristics.

4. For any site, gaged or ungaged, the magnitude of a flood of any specified recurrence interval can be found by the combined use of the regional and area curves. If desired, a frequency curve for any site can be obtained by repeating this process for various recurrence intervals. 
All gaging-station records used in this report exhibited similar frequency characteristics and, therefore, one regional flood-frequency curve was sufficient for the entire area. The only basin characteristic found to correlate significantly with mean annual flood was drainage area. Division of the region into three hydrologic areas was found to be adequate for the delineation of the relation between mean annual flood and drainage area. Plate 1 shows the region covered by the floodfrequency study subdivided into the hydrologic areas designated as $\mathrm{A}, \mathrm{B}$, and $\mathrm{C}$.

\section{PHYSICAL DESCRIPTION OF THE REGION}

The area of Alaska is approximately 586,000 square miles, about one-third of which is covered in this report. The region studied contains wide variations in topography from Mount McKinley, the highest point on the North American continent, to the flat, low-lying tundra plains. A short description of the more pronounced characteristics of the region studied follows.

\section{AREA A}

Area A contains approximately 50,000 square miles: 35,000 in the southeastern "panhandle," 10,000 bordering the Gulf of Alaska, and 5,000 in the Kodiak Island group.

The southeastern "panhandle," a mountainous mass intricately cut by waterways, is about 300 miles long and contains hundreds of islands, six of which are each more than 1,000 square miles in area. During the ice ages, all the valleys and most of the mountains of both the mainland and the islands were covered by great ice sheets that extended to the Pacific Ocean. Many of the stream basins were strongly modified by this glaciation, as their present characteristic glacial geomorphology still shows.

The area bordering the Gulf of Alaska from the 141st meridian to the Copper River delta is largely mountainous and is interspersed with extensive glacial outwash plains. From the Copper River delta to the tip of the Kenai Peninsula the coast is extremely rugged and irregular, indented by numerous arms, fjords, and inlets, many of which terminate at the face of glaciers. The entire area bordering the Gulf of Alaska may be generally classified as rugged, largely glacier-covered mountains that rise abruptly from tidewater.
Kodiak Island is a mountainous area deeply cut by long arms of the sea that extend many miles into the land mass. The mountains forming the backbone of the island trend northeast, reach an elevation of 5,000 feet, and are capped with snow or glaciers. The streams on the southern side of the mountains are short and steep, and have small drainage areas. The streams on the northern side of the mountains may attain considerable length and large flow before entering tidewater.

\section{AREA B}

Area B contains approximately 120,000 square miles and consists of the following drainage areas:

1. The Copper River basin comprises a complex stream system which drains a vast intermountain region lying among the Chugach Mountains, Wrangell Mountains, and Alaska Range. On the northwest, however, a high level plateau, characterized by numerous lakes and poorly defined drainage, divides the Susitna River basin from the Copper River basin. Nearly 75 percent of the area within the Copper River basin lies in extremely rugged terrain of the mountain ranges that form most of its boundaries.

2. The Susitna River basin is bounded by the Alaska Range, the Talkeetna Mountains, and the indistinct boundary of the Copper River basin. For the most part the main streams lie in deep canyons, but in the 100 miles immediately above its mouth the Susitna River flows through a broad flat valley whose average width is 50 miles.

3. The Knik-Matanuska River system drains the very steep area of the Talkeetna and Chugach Mountains north of Cook Inlet.

4. The drainage of the Cook Inlet area south of the Susitna system consists of a large number of small streams discharging directly into the Inlet or its two arms.

5. The area west of the Aleutian Range and south of the Ahklun Range is drained by streams discharging into Bristol Bay. The streams in this area are generally characterized by lakes in their basins. The large lakes are generally of glacial origin, long, relatively narrow, and very deep. The bottoms of many lakes are several hundred 
feet below sea level. These lakes are in contrast to the thousands of small, shallow, generally unnamed tundra lakes that conform to no drainage pattern and have neither inlets nor outlets. The stream profiles of this area are generally steep above the larger lakes, and quite moderate in the lower reaches where the streams meander through braided channels across the wide coastal plains.

\section{AREA C}

Area C contains approximately 40,000 square miles, most of which comprises the Tanana River system. The Tanana River is formed by the confluence of the Chisana and Nabesna Rivers, and flows in a northwesterly direction until it joins the Yukon River at the town of Tanana. The river flows through a valley whose width ranges from 10 to 15 miles, until it widens to 50 to 60 miles near Big Delta.

Area $\mathrm{C}$ is flanked on the south by the Alaska Range and the Wrangell Mountains. This mountain area has been intensely glaciated and, consequently, the valleys are Ushaped and deeply filled with morainal and glaciofluvial material. On the north the area is bounded by mountains of low elevation. The mountains have not been glaciated extensively, and therefore contain $\mathrm{V}$-shaped valleys formed on the underlying bedrock formations.

\section{CLIMATE OF THE REGION}

\section{AREA A}

The climate of area $A$ is maritime, characterized by mild winters and cool summers. The Aleutian low in the winter and the continental low in the summer cause inflows of relatively warm, moist air. The orographic lifting of the air flows caused by the mountain ranges produces precipitation greatly in excess of that which would occur if no topographic barriers existed. The precipitation pattern is generally characterized by high annual amounts, long duration, and low intensity. However, this pattern is subject to wide variations in short distances. The maximum observed 24-hour rain is 10.94 inches, measured at Little Port Walter.

\section{AREA B}

In the Copper River basin the Chugach Mountains which form the southern boundary of area $B$, force the maritime air flowing into the region to precipitate its moisture in area A. Because of the interception of the maritime air, the region is dry and cold. The annual precipitation ranges from 9 to 22 inches, measured at rather low elevations. The climate of the Susitna River basin is similar to that of the Copper River basin, but the lower reaches of the Susitna Valley receive more precipitation. In general, the Cook Inlet area has climatic conditions that are transitional between those of the wet and mild coastal regions and those of the dry and cold interior regions of Alaska. Within the area, however, a wide variation in climate results from topographic effects on the flow of air. The climate of the Bristol Bay area, west of the Aleutian Range and south of the Ahklun Range, is sometimes considered maritime but is subject to large variations due to continental influences. Precipitation over the area is largely the result of orographic lifting and frontal activity associated with the Aleutain low. The frequency and intensity of smaller lows and fronts within the Aleutian low at various seasons largely determine the precipitation pattern of the area. About 50 percent of the area's precipitation occurs from July to October. The average annual precipitation measured at low elevations ranges from 20 to 30 inches. The area is usually not subject to high-intensity, shortduration storms.

\section{AREA C}

The climate of area $\mathrm{C}$ is continental, characterized by cold, dry winters and warm but relatively moist summers. Large temperature differences occur in this area because the several mountain ranges to the south form an effective barrier to the flow of warm, moist air from the north Pacific Ocean. Precipitation is low in total amount, ranging from about 10 to 22 inches annually, and it is light; the maximum recorded for a 24-hour period is only 4.00 inches.

\section{FLOOD-FREQUENCY ANALYSIS}

\section{RECORDS AVAILABLE}

Annual peak-discharge records 5 or more years in length from 61 gaging stations in Alaska were used in the analysis. All other records were rejected for one or more of the following reasons: 62.

1. Outside the selected base period, 1948- 


\section{Significant flood regulation.}

3. Insufficient data to define a hydrologic area.

Studies of the magnitude and frequency of floods for the larger rivers, that is greater than 10,000 square miles, were not included because of the short periods of record and paucity of data on comparative drainage areas.

\section{FLOOD FREQUENCY AT A GAGING STATION}

SIGNIFICANCE AND UTILIZATION

The frequency curve (based on records of the individual gaging station) defines the past flood history at the gaging-station site. Site frequency curves for a homogeneous region are compiled and combined to derive the regional flood-frequency curve. In general, the regional flood-frequency curve is considered a more reliable guide for estimating future floods than a curve based only a records for an individual gaging station, even for the gaging-station site.

The station flood record is considered a short-time sample of past floods from an indefinitely long succession of past and future floods generally exhibiting widely varying magnitudes of chance occurrence. On the basis of this assumption, Dalrymple (1960) shows that reliability of the definition of flood characteristics increases with length of record, particularly for floods of recurrence intervals of less than 50 years. Accuracy of definition of mean annual flood within 25 percent seems attainable with 10 to 20 years of record.

\section{TYPES OF FLOOD SERIES}

Flood data for frequency analysis may be arranged in an annual-flood series or in a partial-duration series. An annual flood is defined as the highest momentary peak discharge in a water year. Partial-duration series include all individual momentary peak discharges above a selected base discharge. For partial-duration series, some years will have several qualifying peaks and other years none.

This report is based on annual-flood data. Recurrence intervals evaluated from annual floods can be converted to values that would be obtained from the partial-duration series by the following table (Langbein, 1949):

Recurrence intervals, in years
Annual-flood series

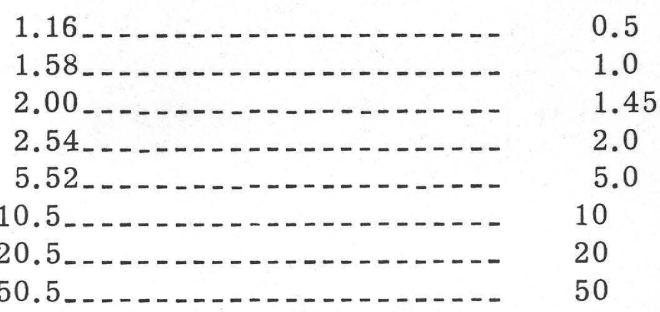

PLOTTING POSITIONS
Partialduration series$$
0.5
$$

5.0

10

20
Flood peaks were listed for each gaging station and ranked according to magnitude, the highest peak being numbered 1. Plotting positions (recurrence intervals) for each flood were computed by using the formula $R I=\frac{(n+1)}{m}$ where RI is the recurrence interval, $n$ is the number of years of record, and $m$ is the order number.

Annual floods versus recurrence intervals were plotted on a special form (Powell, 1943); the resulting curve of relation for many stations is a straight line.

Recurrence interval, as used in this report, is the average interval within which the given flood will be equaled or exceeded once as the annual maximum over a long period of time. This concept does not imply any regularity of occurrence.

\section{FITTING FREQUENCY CURVES}

A final step in defining the annual floodfrequency history for the gaging station required fitting a curve to the plotted points. A visually fitted smooth curve was drawn with consideration for the following items:

1. Use of a straight line where possible.

2. Most weight given to the lower and middle points.

3. Little weight given to the few highest points where they were incompatible with items 1 and 2 above. 
REGIONAL FLOOD FREQUENCY

Regional flood-frequency methods were adopted for the analysis in preference to flood-frequency results based on single gaging-station records. The latter are unreliable if the length of record does not exceed the selected recurrence interval or if the time sample is not representative of longterm conditions. Also, flood-frequency information is usually needed for ungaged sites and can be obtained from the regional analysis but not from frequency curves for individual stations.

REGIONAL HOMOGENEITY OF RECORDS

The individual station records were subjected to a statistical test to insure homogeneity of records throughout the region. That is, the ratio of the 10-year flood to the mean annual flood was computed for each station. This ratio, in effect, is a measure of the slope of the frequency curve. The variation in slopes of frequency curves for the 61 stations included in the analysis was found to be well within the range that could occur by chance within a single population.

COMPOSITE FREQUENCY CURVE

The regional composite frequency curve was drawn as shown in figure 1; flood magni- tude is expressed as a ratio to the mean annual flood. Reduction of flood magnitude to dimensionless for $m$ permits general regional use of the curve. The actual construction of the composite frequency curve was accomplished as follows:

For various selected recurrence intervals, the ratio of flood magnitude to mean annual flood was computed for each gaging station. The median ratio for each recurrence interval was plotted against that recurrence interval and a smooth curve was drawn through the plotted points.

MEAN ANNUAL FLOOD

The mean annual flood for a given station is the mean of all annual floods at that site and should not be confused with the flood having a recurrence interval of 1 year. The recurrence interval of the mean annual flood is 2.33 years according to the theory of extreme values as applied to floods by Gumbel (1945). In this report the mean annual flood for each gaging station, determined graphically from the individual station frequency curve, is the discharge value at the intersection of the curve with the line representing the 2.33year recurrence interval.

Because flood magnitudes for the regional flood-frequency curve are expressed as a

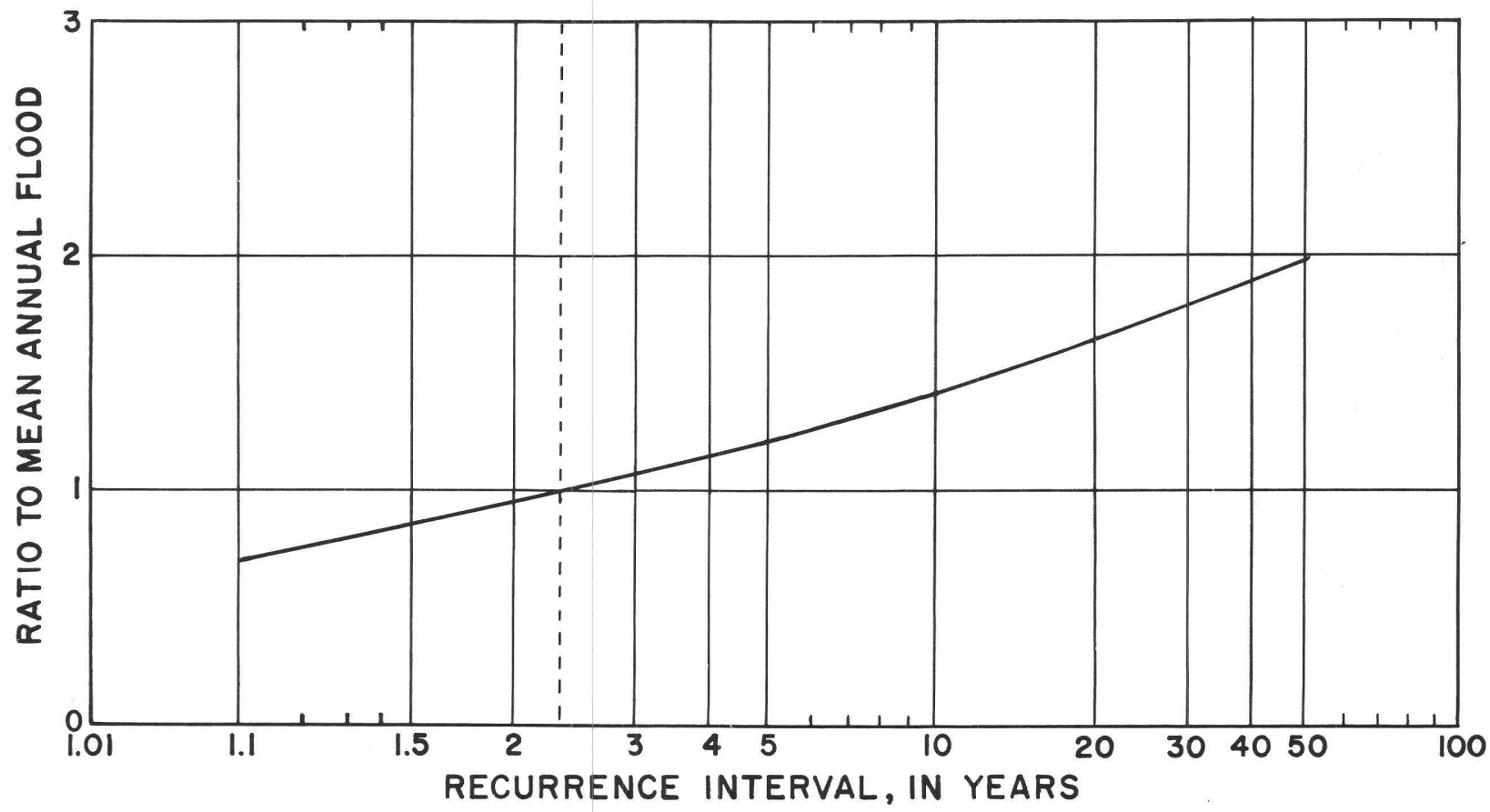

Figure 1,-Composite flood-frequency curve. 
ratio to the mean annual flood, it follows that application of the regional curve requires a knowledge of the mean annual flood. That is, the regional curve cannot be used to compute the expected recurrence interval of a flood of a given magnitude at a specific site unless the mean annual flood for that site can be computed. The magnitude of the mean-annual flood depends in part on physical characteristics of the basin. As expected, correlation of mean annual flood with size of drainage basin was found to be significant. However, multiple correlation of mean annual flood with other measured characteristics of the drainage basins such as altitude, channel slopes, areas of lakes or glaciers, latitude, and mean annual runoff yielded little or no significant improvement because there is as yet, not enough data to define adequately relations with these other characteristics. Drainage area was, therefore, the only basin charac- teristic used for direct correlation with mean annual flood.

\section{HYDROLOGIC AREAS}

As shown earlier, all station records were found to be within one homogeneous region with respect to slope of frequency curves. It does not follow, however, that all stations are in one homogeneous area with respect to correlation between mean annual flood and drainage area, because varying meteorologic and geologic conditions can cause significant areal variation in that correlation. Trial and error groupings of gaging stations showed that the region could be split into three hydrologic areas within which stations correlate reasonably well with size of drainage area. These areas are designated as A, B, and C on plate 1 , and figures 2,3 , and 4 show the relation between mean annual flood and drainage area for those respective areas.

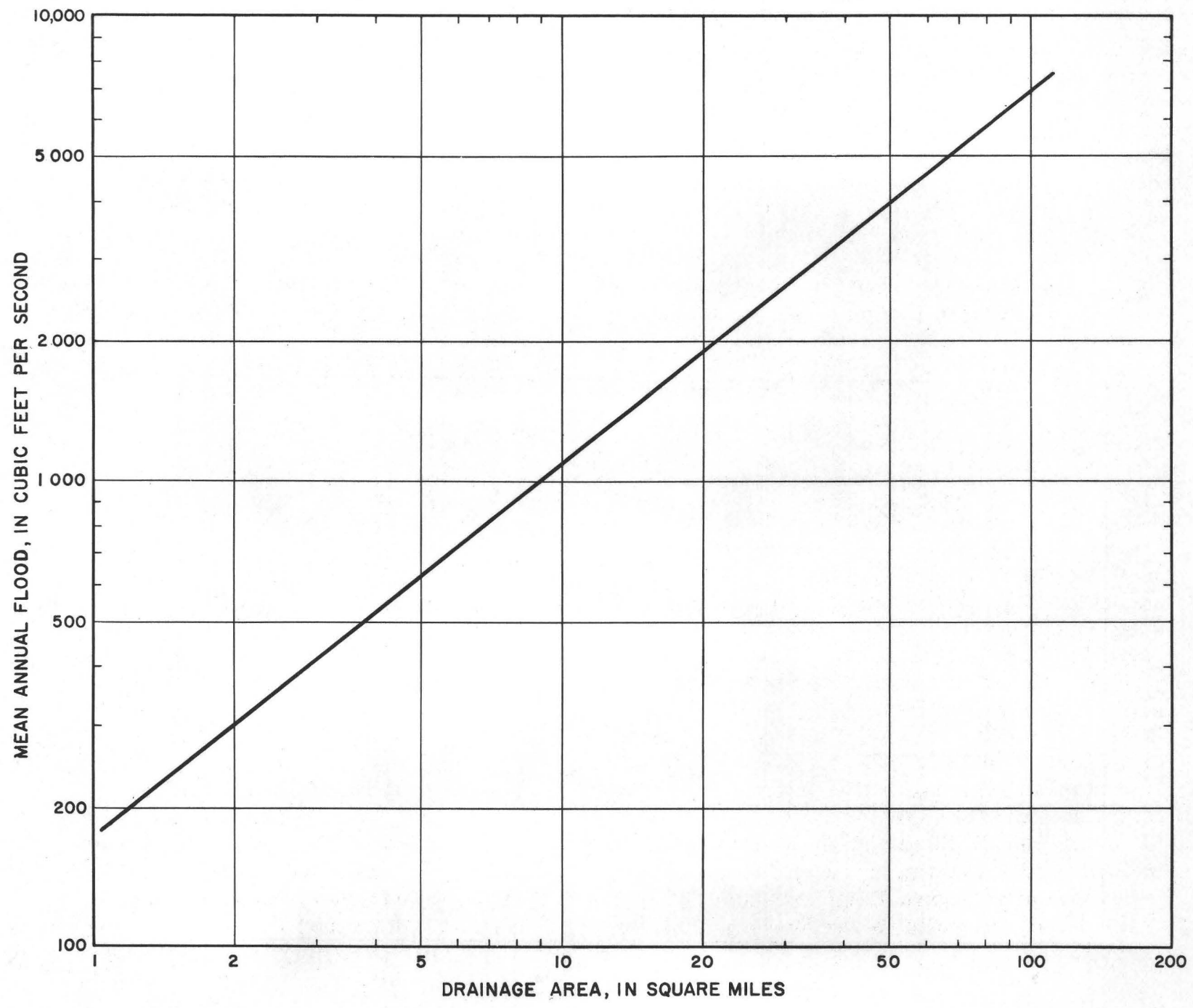

Figure 2. -Variation of mean annual flood with drainage area in hydrologic area A. 


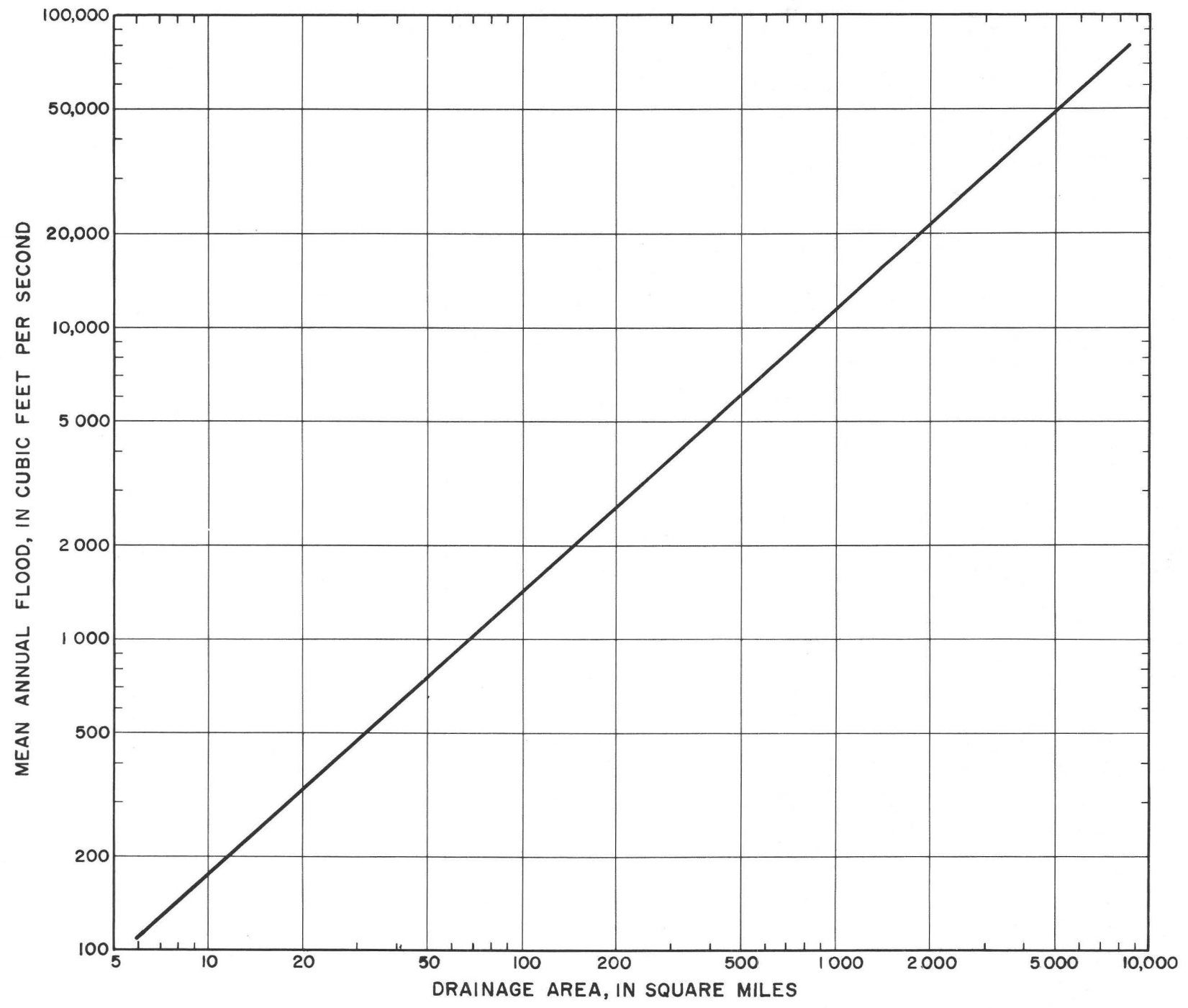

Figure 3.-Variation of mean annual flood with drainage area in hydrologic area B.

MAXIMUM KNOWN FLOODS

Where failure of structures might cause loss of life, the designer usually considers the maximum known flood or the maximum probable flood as well as one expected to occur in a specified period of years. Records of maximum known floods collected in the course of surface-water investigations are therefore a valuable guide.

Maximum known floods for gaging stations used in this regional flood-frequency analysis are listed in table 1. Also listed are the areal mean annual flood and the recurrence interval for the maximum known flood. Where the maximum known flood exceeds the 50year flood, its ratio to the 50-year flood is shown.
Maximum known floods are plotted on figures 5, 6, and 7 to show graphical comparisons with areal 10-year and 50-year floodrelation curves. Station numbers and the corresponding hydrologic area listed in table 1 identify the peaks on the graphs and locate the gaging stations on plate 1 .

\section{UNUSUAL FLOODS AT SHORT-TERM GAGING STATIONS}

A search of all gaging-station records in the State for unusual floods yielded the additional flood information shown in table 2 . This table shows all known maximum floods greater than the 50-year flood that are not listed in table 1. The floods have been plotted on the appropriate hydrologic area curves in figures 5,6 , and 7 . 


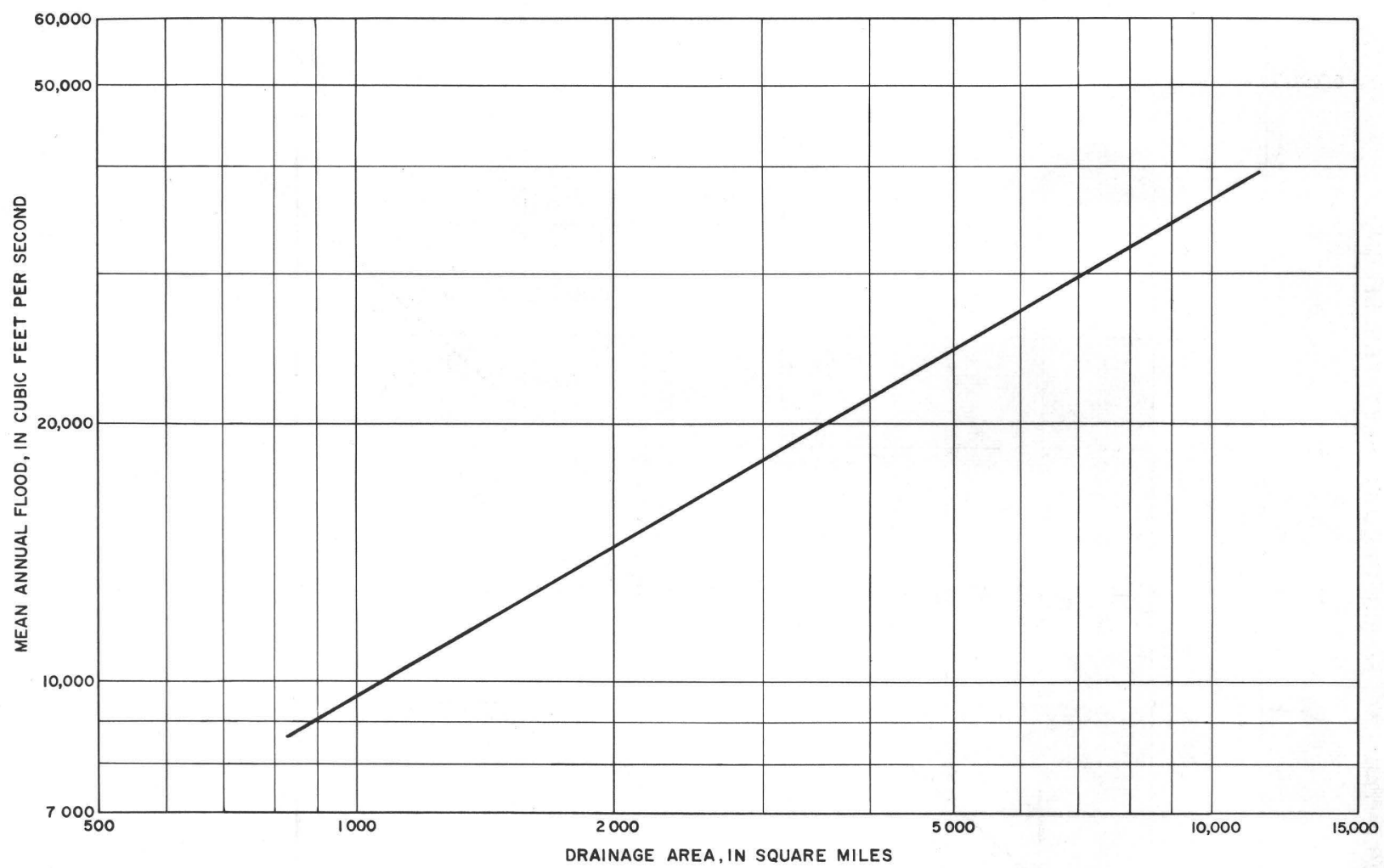

Figure 4.-Variation of mean annual flood with drainage area in hydrologic area $\mathrm{C}$.

\section{SUMMARY AND CONCLUSIONS}

Magnitude of a flood at any point, gaged or ungaged, in the region covered by the study and corresponding to a specified recurrence interval can be obtained by using the method described in this report. The procedure is as follows:

1. Enter the composite frequency curve (fig. 1) with the specified recurrence interval to obtain the flood magnitude expressed as a ratio to mean annual flood.

2. Determine the drainage area above the site and the hydrologic area within which the drainage area falls.

3. Enter the appropriate hydrologic area curve (fig. 2,3 , or 4 ) with the drainage area to obtain magnitude of mean annual flood, in cubic feet per second.

4. Multiply the ratio obtained at step 1 by the mean annual flood obtained at step 3 to get the magnitude of the flood, in cubic feet per second.

Computations can be reversed to compute the recurrence interval for a flood of speci- fied magnitude. Further, through repetition of steps 1 and 4 for various recurrence intervals, a frequency curve for the site can be obtained. A frequency curve derived from regional data is considered more reliable than a curve based on data for a single gaging station because the inclusion of data for the larger region tends to modify local non-typical occurrences.

All known flood data for this region in Alaska were used in the analysis, but records are short and density of gaging stations is low. Reliability of data should be greatly improved when reanalysis, using more and longer records, can be made at some future date. Correlation of the mean annual flood with additional factors as well as with drainage area may significantly increase accuracy in results.

For the present, flood-frequency data obtained using the method outlined above represent the most probable values expected over a long period of time. None of the curves can be extended with confidence beyond the limits shown, and data obtained for the higher recurrence intervals should be used with caution. 


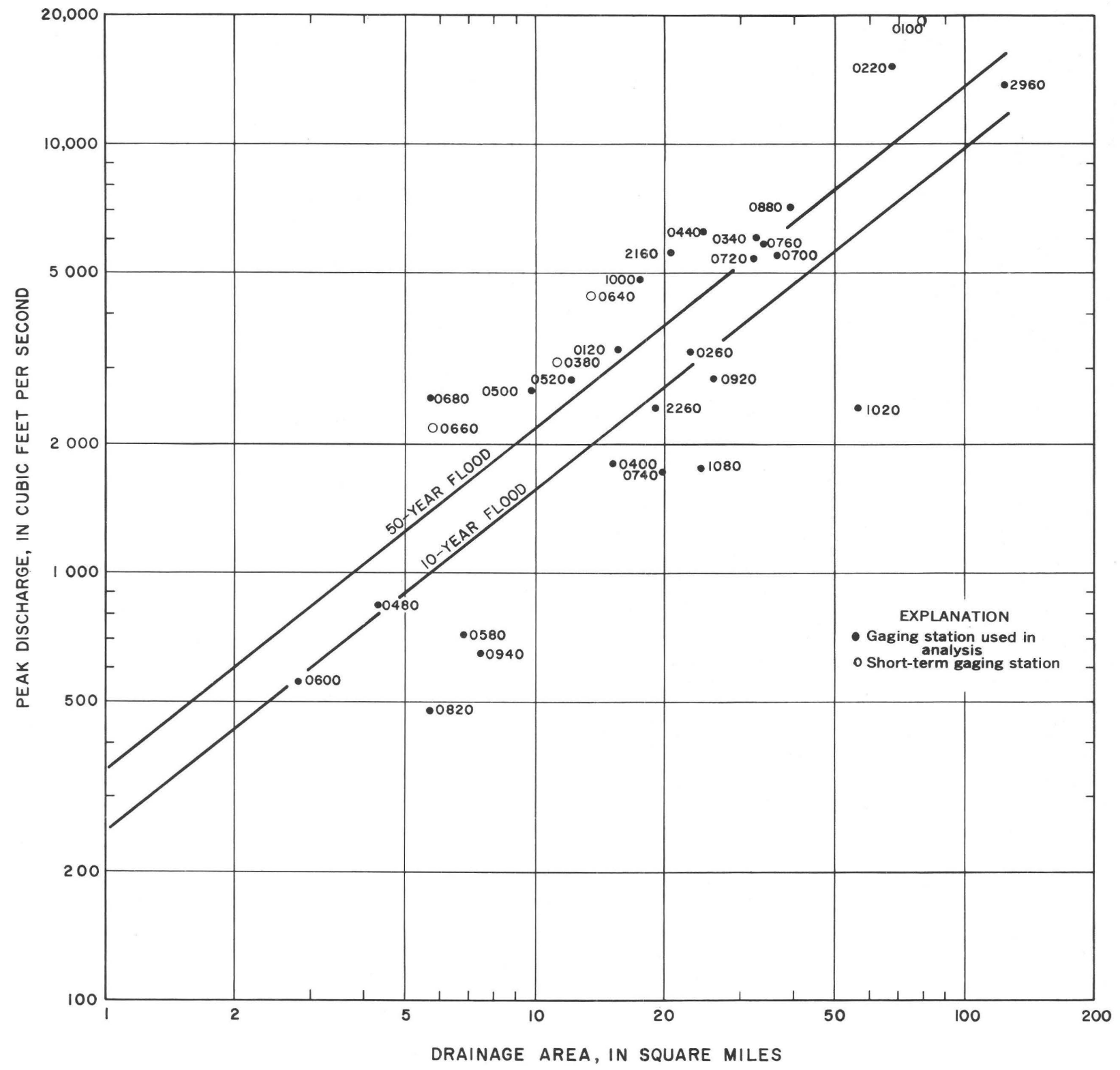

Figure 5. - Relation of maximum to 10 - and 50-year floods in hydrologic area A. 


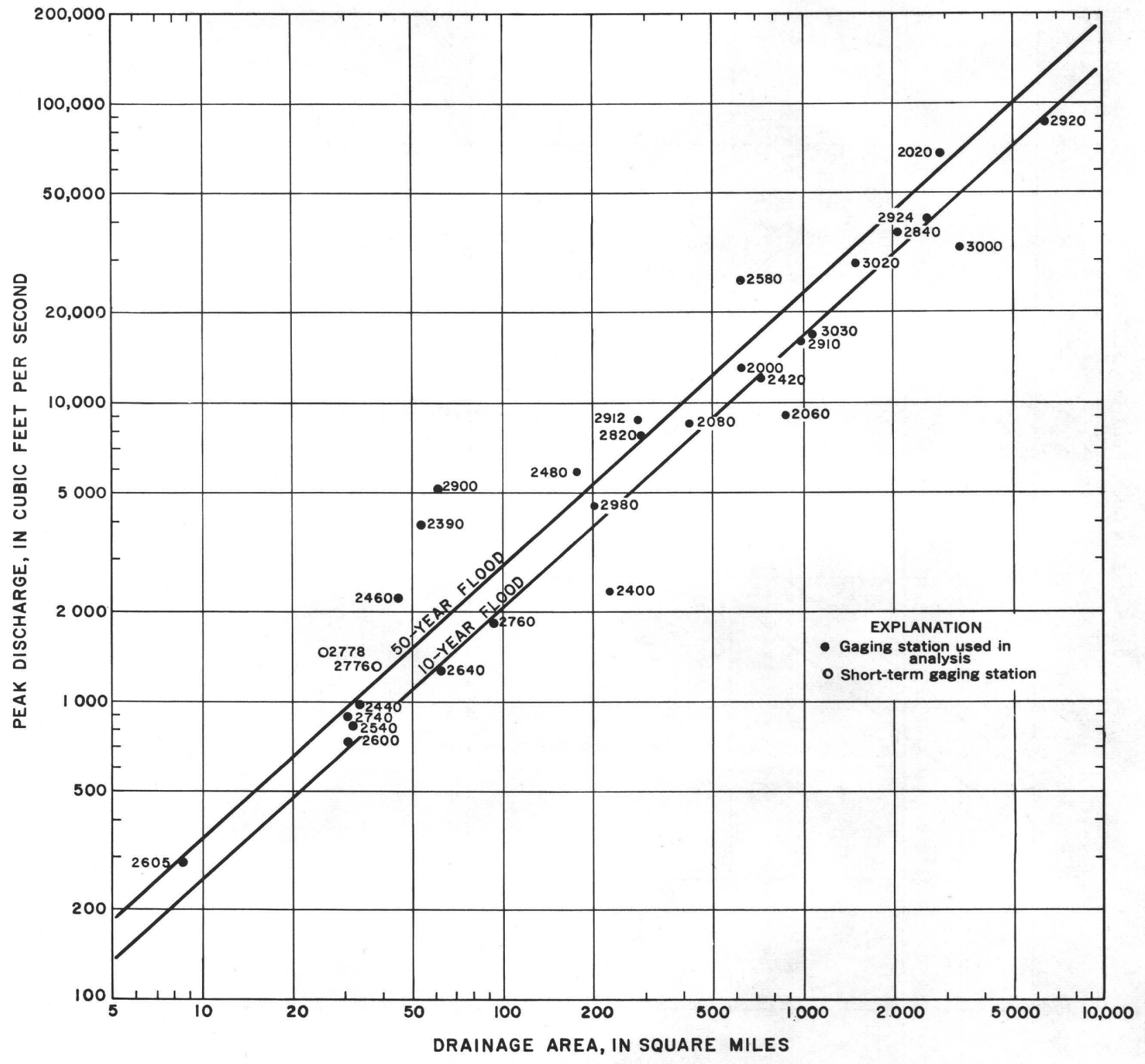

Figure 6.-Relation of maximum to 10 - and 50 -year floods in hydrologic area B. 


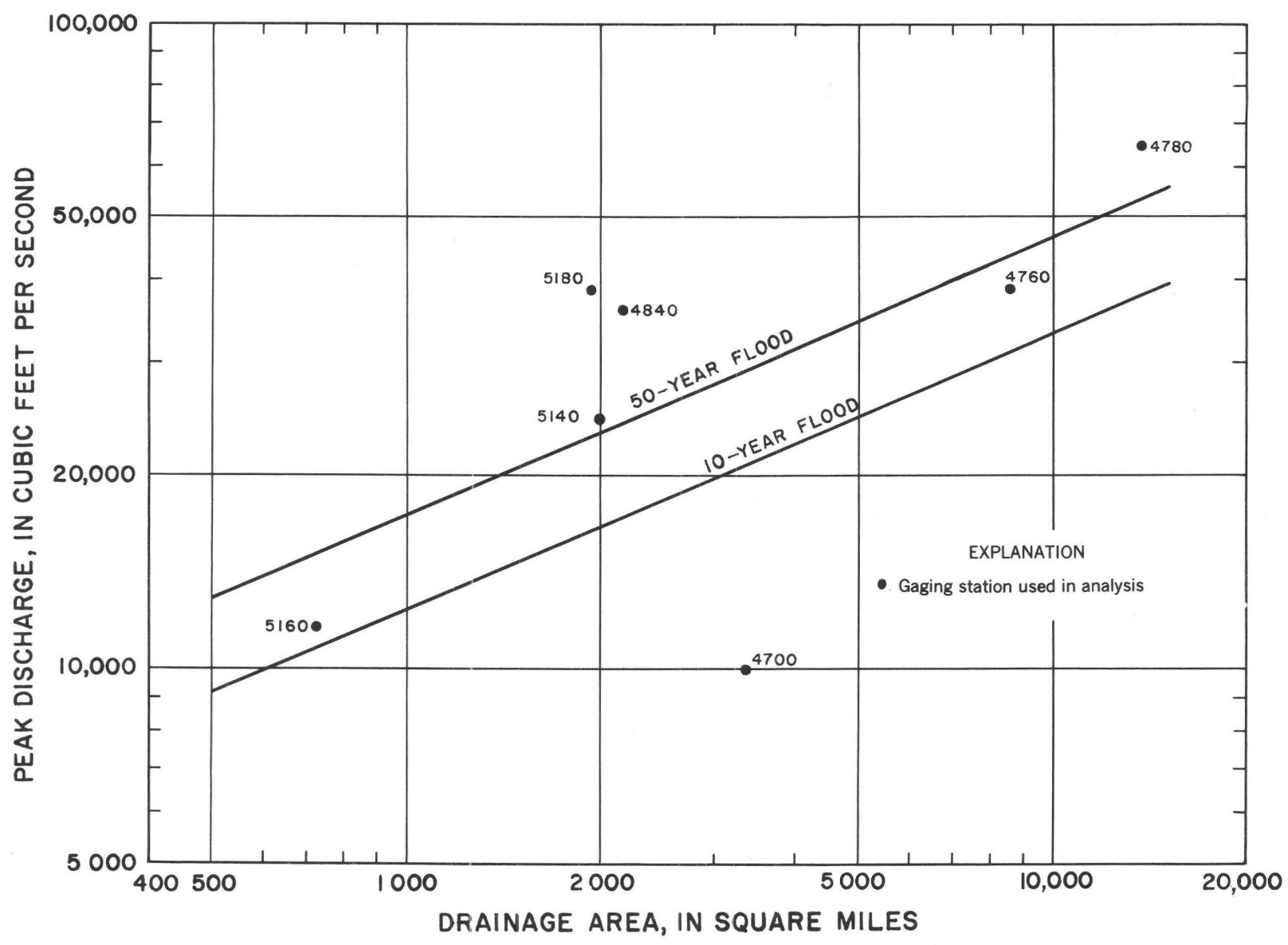

Figure 7.-Relation of maximum to 10 - and 50 -year floods in hydrologic area $\mathrm{C}$.

\section{SELECTED REFERENCES}

Berwick, V. K., 1962, Floods in Utah, magnitude and frequency: U.S. Geol. Survey Circ. 457.

Dalrymple, T., 1960, Flood-frequency analyses: U.S.Geol. Survey Water-Supply Paper 1543-A.

Green, A. R., and Hoggatt, R. E., 1960, Floods in Indiana, magnitude and frequency: U.S, Geol. Survey open-file report.
Gumbel, E. J., 1945, Floods estimated by the probability method: Eng. News Rec., June 14, p. 97-101.

Langbein, W. B., 1949, Annual floods and the partial-duration flood series: Am. Geophys. Union Trans., v. 30, p. 879-881.

Powell, R. W., 1943, A simple method of estimating flood frequencies: Civil Eng., v. 13, no. 2, p. 105-106. 
Table 1. - Maximum stages and discharges at gaging stations

\begin{tabular}{|c|c|c|c|c|c|c|c|c|c|c|}
\hline \multirow[b]{3}{*}{ No. } & \multirow{3}{*}{$\begin{array}{r}\text { Gaging station } \\
\text { Stream }\end{array}$} & \multirow{3}{*}{$\begin{array}{l}\text { Hydro- } \\
\text { logic } \\
\text { area } \\
\text { (pl. 1) }\end{array}$} & \multirow{3}{*}{$\begin{array}{l}\text { Drain- } \\
\text { age } \\
\text { area } \\
\text { (sq } \mathrm{mi} \text { ) }\end{array}$} & \multirow{3}{*}{$\begin{array}{l}\text { Period } \\
\text { of } \\
\text { known } \\
\text { floods }\end{array}$} & \multicolumn{4}{|c|}{ Maximum stage and discharge } & \multirow{3}{*}{$\begin{array}{c}\text { Areal } \\
\text { mean } \\
\text { annual } \\
\text { flood } \\
(Q 2.33 \\
\text { in cfs) }\end{array}$} & \multirow{3}{*}{$\begin{array}{c}\text { Recurrence } \\
\text { interval } \\
\text { (years) }\end{array}$} \\
\hline & & & & & \multirow[b]{2}{*}{ Date } & \multirow{2}{*}{$\begin{array}{l}\text { Gage } \\
\text { height } \\
\text { (feet) }\end{array}$} & \multicolumn{2}{|c|}{ Discharge } & & \\
\hline & & & & & & & Cfs & $\begin{array}{l}\text { Cfs per } \\
\text { square } \\
\text { mile }\end{array}$ & & \\
\hline
\end{tabular}

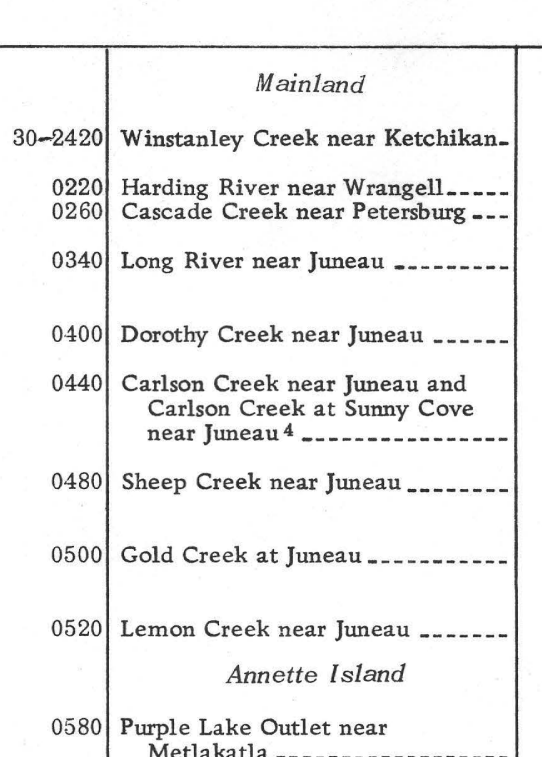

Southeastern Alaska

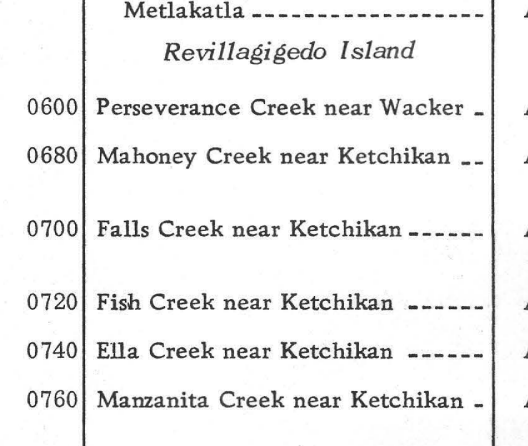

Prince of Wales Istand

0820 Reynolds Creek near Hydaburg -..-

\section{Baranof Island}

0880 Sawmill Creek near Sitka

0720 Maksoutof River near Port

Alexander............

0940 Deer Lake Outlet near Port

1000 Alexander. Takatz Creek near Baranof.....

Admiralty Island

1020 Hasselborg Creek near Angoon -.-

Chichagof Island

1080 Pavlof River near Tenakee

\begin{tabular}{l|l|l|l} 
A & 55.7 & $1951-56$ & Feb. 2,1954
\end{tabular}

A

A

A

A

A

A

A

A

A

A

A

A

A

A

$24.3 \quad \begin{gathered}1915-20, \\ 1951-61 \\ 1911-13, \\ 1916-20 \\ 1946-62\end{gathered} \mid$ Sept. 26, 1918

$9.761916-20$, Aug. 12, 1961 1946-48,

$12.1 \begin{gathered}1949-62 \\ 1951-62\end{gathered} \mid$ Aug. 13, 1961

\begin{tabular}{l|l|l}
${ }^{5} 6.8$ & $1947-56$ & Apr. 27,1949
\end{tabular}

2.81 1931-39, Oct. 14, 1960

$5.70 \begin{gathered}1920-25, \\ 1926-33\end{gathered}$ 1926-33, 1947-58

36.5 1916-26, Nov. 1, 1917 1927-33

$\left.32.1 \quad \begin{array}{c}1946-59 \\ 1915-35, \\ 1938-62\end{array}\right]$ Oct. 15, 1961

$19.71927-38$, Dec. 7, 1930

$33.9 \quad \begin{gathered}1947-58 \\ 1927-37,\end{gathered}$ Oct. 14, 1961 1947-62

\begin{tabular}{l|l|ll}
5.7 & $1951-56$ & Feb. 2, 1954
\end{tabular}

39.0 1920-22, Sept. 8, 1948 $1928-42$ 1945-57

A

A

$17.5 \quad 1951-62$

Oct. 22,1953

$526.0 \quad 1951-56$

Sept. 14,1952

A

56.2 1951-62 Oct. 23, 1953

24.3 1957-62 Aug. 13, 1961

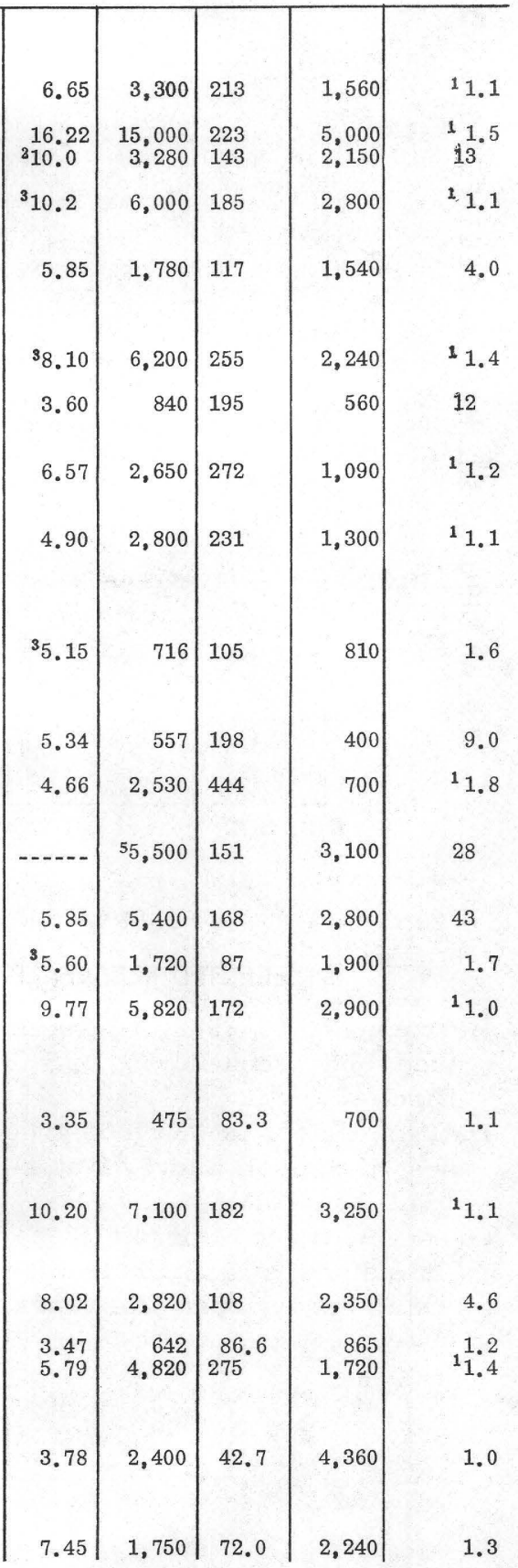

1.3

See footnotes at end of table. 
Table 1. - Maximum stages and discharges at gaging stations-Continued

\begin{tabular}{|c|c|c|c|c|c|c|c|c|c|c|}
\hline \multicolumn{2}{|r|}{ Gaging station } & \multirow{3}{*}{$\begin{array}{l}\text { Hydro- } \\
\text { logic } \\
\text { area } \\
\text { (pl. 1) }\end{array}$} & \multirow{3}{*}{$\begin{array}{l}\text { Drain- } \\
\text { age } \\
\text { area } \\
(\text { sq } \mathrm{mi})\end{array}$} & \multirow{3}{*}{$\begin{array}{l}\text { Period } \\
\text { of } \\
\text { known } \\
\text { floods }\end{array}$} & \multicolumn{4}{|c|}{ Maximum stage and discharge } & \multirow{3}{*}{$\begin{array}{c}\text { Areal } \\
\text { mean } \\
\text { annual } \\
\text { flood } \\
(Q 2.33 \\
\text { in cfs) }\end{array}$} & \multirow{3}{*}{$\begin{array}{c}\text { Recurrence } \\
\text { interval } \\
\text { (years) }\end{array}$} \\
\hline \multirow[b]{2}{*}{ No. } & \multirow[b]{2}{*}{ Stream } & & & & \multirow[b]{2}{*}{ Date } & \multirow[b]{2}{*}{$\begin{array}{l}\text { Gage } \\
\text { height } \\
\text { (feet) }\end{array}$} & \multicolumn{2}{|c|}{ Discharge } & & \\
\hline & & & & & & & Cfs & $\begin{array}{l}\text { Cfs per } \\
\text { square } \\
\text { mile }\end{array}$ & & \\
\hline
\end{tabular}

Alaska west of long $141^{\circ}$

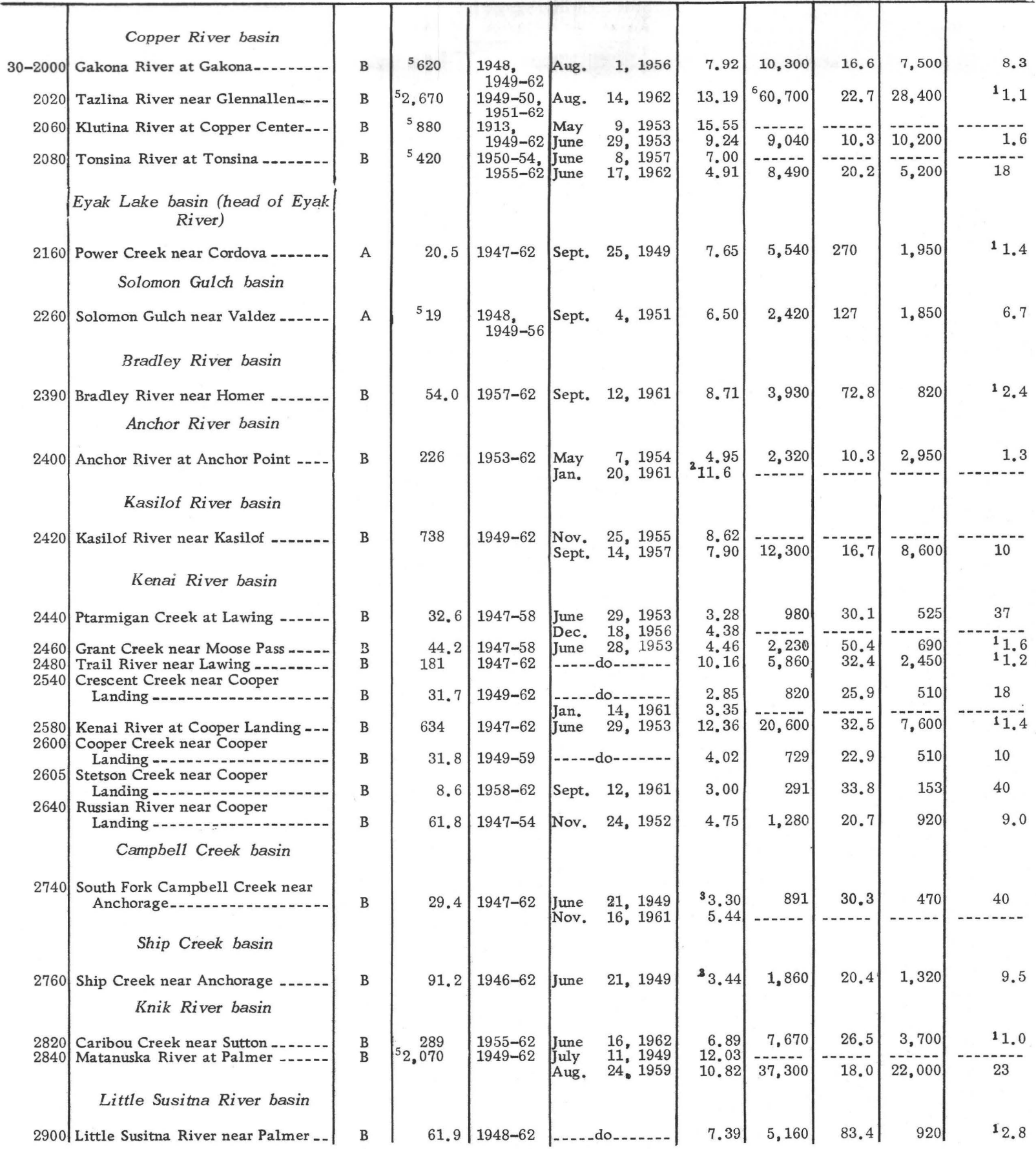

See footnotes at end of table. 
Table 1. -Maximum stages and discharges at gaging stations-Continued

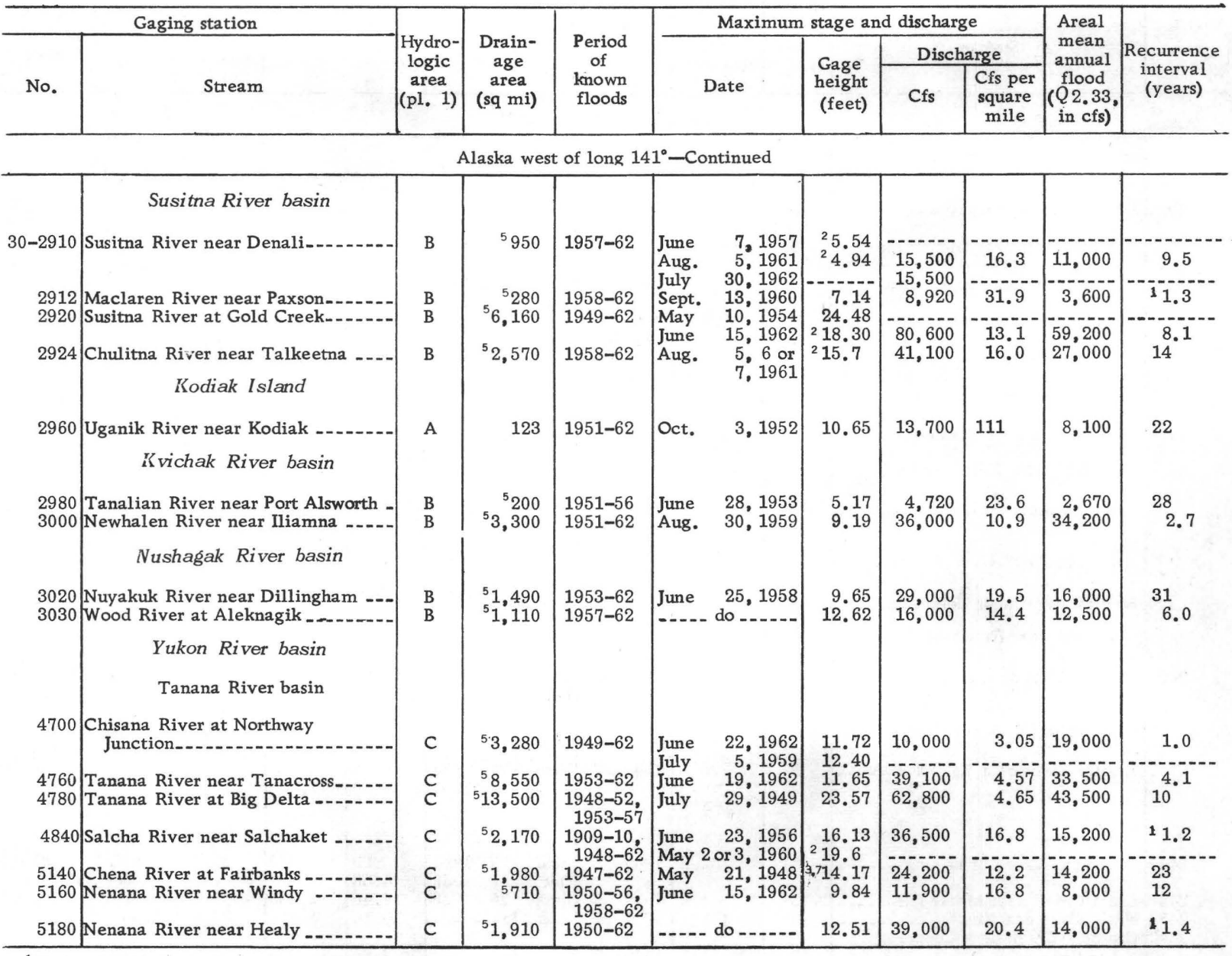

${ }^{1}$ Ratio of peak discharge to that of 50 -year flood.

${ }^{2}$ From floodmark.

${ }^{3}$ Datum then in use.

${ }_{5}^{4}$ Equivalent records combined.

${ }^{5}$ Approximate.

${ }^{6}$ Caused by release of water impounded behind ice dam upstream.

${ }^{7}$ Flood in August 1930 reached a stage of about $15.2 \mathrm{ft}$, present datum (according to information from local residents); flood of May 1114, 1937, reached a stage of $15.9 \mathrm{ft}$, present datum, because of ice jam (from floodmarks). 
Table 2. -Unusual floods at short-term gaging stations

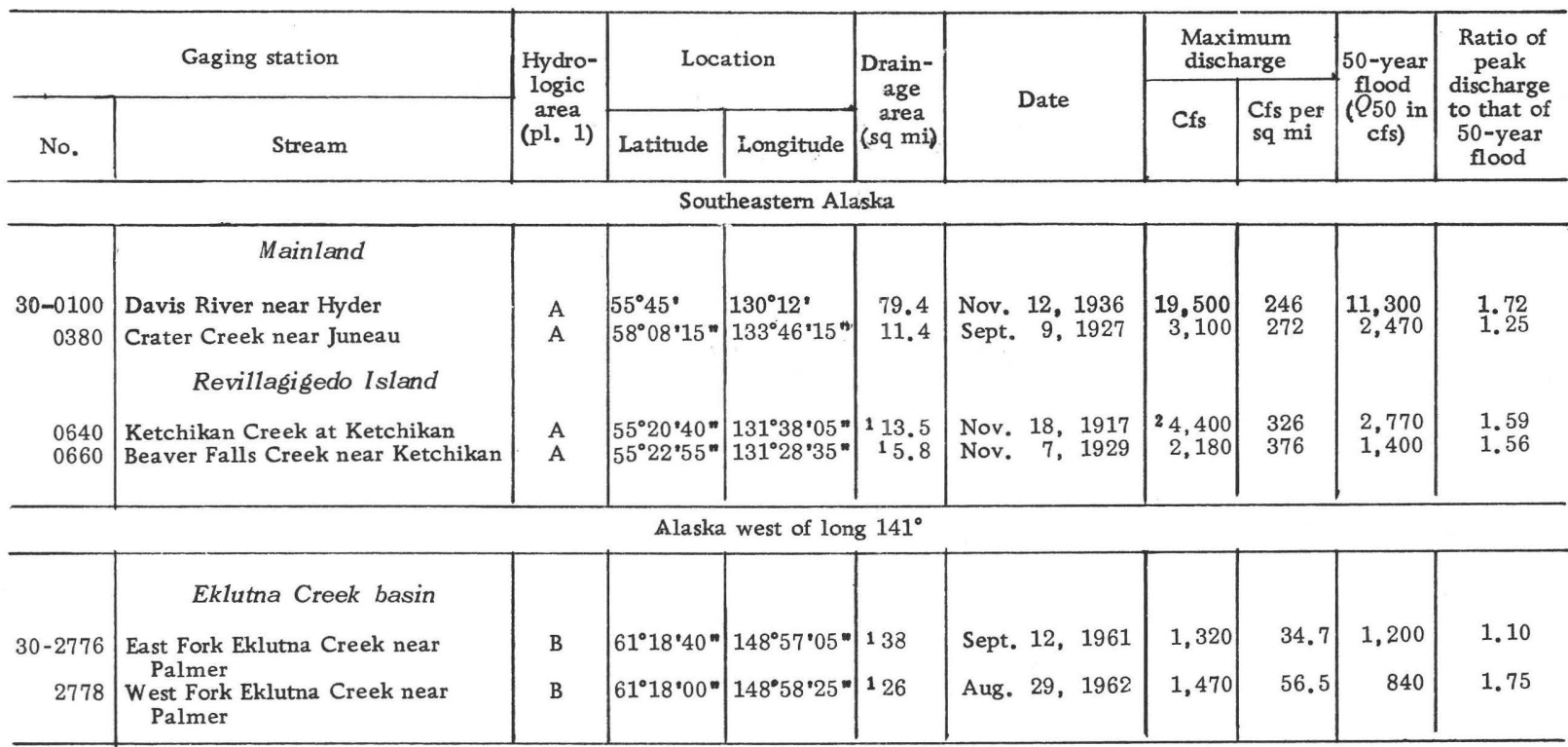

1 Approximate.

${ }^{2}$ Maximum observed; flow regulated by Ketchikan Lakes. 